\title{
European Integration in the Aftermath of the Debt Crisis
}

\author{
Christopher A. Hartwell \\ Elias Soukiazis \\ Eva Muchová \\ Roman Horváth
}

Despite a timid recovery in growth after the global financial crisis, the economic crisis in the European Union is far from over, and the effects of the crisis continue to linger. Real GDP in the fourth quarter of 2016 in the EU was only 5\% higher than in the first quarter of 2008, showing a remarkable stagnation for a region used to steady (if unimpressive) growth. The situation in the Euro area has shown even less progress, as nearly every country in Western Europe using the euro has stagnated significantly since 2007, with countries in the south of Europe such as Greece and Spain seeing unemployment exceeding 25\%. For all intents and purposes, economic growth in the European Union came to a halt as a result of the crisis, with only a few countries such as Poland showing signs of resilience.

Growth was not the only casualty of the global financial crisis. Indeed, and somewhat ironically, the leap forward in European integration that was the euro may have sowed the seeds of the demise of further integration. In addition to the impact of the global financial crisis, Europe plunged directly into an ensuing sovereign debt crisis, a crisis which exposed the incapability of existing European institutions in dealing with economic problems of this magnitude. While a common currency had been put into practice, legal and regulatory framework deficiencies, combined with the weakness of the euro project itself, created severe difficulties in crisis response. In particular, as Wyplosz (2014) notes, politicians were forced into the role of micromanaging solutions which were usually taken care of by professional bureaucrats. This injection of more politics into a situation already somewhat attributable to national policies made managing the crisis even more difficult.

As already noted, part of the issue plaguing the EU was the euro itself. When individual countries gave up their own currency, they not only facilitated trade and capital flows and reduced transaction costs, but they also gave up the possibility of monetizing their debts. Without any mechanism guaranteeing sovereign debts under a common currency area, this created a ticking time bomb. It is well understood that financial crises tend to work as self-fulfilling prophecies even if justified by the fundamentals, and the slightest loss of confidence might spark a disaster (Cole and Kehoe, 2000). If anything, such an eventuality was underestimated during the pre-crisis period, which was marked by a striking convergence of interest rates on government bonds of EU Member States. Simply put, the issue of an individual country facing a sovereign debt issue under a common currency was never entertained, given that convergence appeared to render such a possibility moot.

Underpinning this assumption was the belief that membership within the European Union and subsequently in the Euro Area would necessarily be accompanied by more prudent fiscal policy, an assumption backed by mechanisms such as the Stability and Growth Pact (SGP) or the 'No Bail-Out 
Clause.' Moreover, the aforementioned inability to monetize debt would also impose a hard-budget constraint, forcing countries to face an upper limit both on debt and deficits. However, with the Greek crisis underway, it becomes clear that these assumptions could be readily discarded by the political pressures inherent in each Member State; mechanisms such as SGP sword were not sufficient to force countries into fiscal rectitude, and the euro itself might encourage profligacy with the implicit guarantee of a bailout. Once financial markets realized that countries such as Italy, Spain, Ireland, Portugal and even France had taken on unsustainable sovereign debts, the nature of the euro guarantee was testes, as interest rates on government bonds soared.

Not only did the pre-crisis institutional mechanisms appear to fail, but the lack of a legal framework for debt-restructuring, an issue which quickly became apparent, also exacerbated the crisis once it was underway. Greek debt was restructured $a d$ hoc and Zettelmeyer et al. (2013) argue that the process surrounding it might make future debt restructuring in Europe even more difficult. Moreover, the debt crisis appeared to have accelerated centrifugal forces in the EU, with the question of Greece leaving the Euro Area or even the European Union became plausible. Politicians and economists had to admit that such measures that our understanding of how this would work was not sufficient (Athanassiou, 2009), another indication that the institutional framework was not well thought-out. The surprise decision of the UK for "Brexit" and the rise of populism in 2016 came as additional destabilizing factors, issues which not only prevented closer integration but which could induce disintegration in Europe.

Facing the lack of political will and the threat of full-fledged self-fulfilling debt crisis, European leaders promptly created the European Financial Stability Facility and the European Financial Stabilisation Mechanism, followed by the European Stability Mechanism. Founding of these mechanisms was far from easy and in fact remained quite contentious at the political level; to take an example, the Slovak Prime Minister was forced to resign as she was unable to obtain the necessary support in her own government for these mechanisms. Worse still, despite these stability mechanisms, the EU did not enjoy any respite and, in fact, integration began to be managed by unelected bureaucrats rather than politicians. In 2012, Mario Draghi crossed the line between monetary and fiscal policy with his 'whatever it takes' and creation of the Outright Monetary Transaction programme. Saka et al. (2015) argue that it was only this measure which managed to calm the markets, but the consequences remain to be seen.

These events, and especially the effect that they have had on the "ever-closer union" in Europe, are the animating reason for this special issue of the Journal of Economic Policy Reform, a journal which is known for tackling policy issues of contemporary interest. What are the prospects for European integration after the debt crisis, and how are the different facets of Europe's economic and political system affecting this process? Are the proposed solutions to the EU's institutional issues appropriate, or, as Burns et al. (2017) show, are they another manifestation of fragmentation in the Union, driven by interests in each Member State? The papers in this issue have been culled from separate events hosted by organizations in which the guest editors are involved: the first, the INFER Workshop on European Integration in the Aftermath of Debt Crisis, took place in Slovakia in March 2016, while the second, the Center for Social and Economics Research's (CASE) 25 th Anniversary Conference on the Future of Europe, took place in November 2016 in Warsaw. Most importantly, the papers collected in this special issue have been selected for their unique approach to the myriad of issues which the EU, growth, and socio-economics on the continent face in particular. 
The papers can be loosely grouped into three thematic areas: policy uncertainty, effects of and responses to the last crisis, and predicting the next crisis. The first paper from Christopher Hartwell builds on the current literature in economic policy uncertainty to show how political volatility in the new EU countries and countries on the EU periphery fed through to financial volatility, suggesting that political changes have economic consequences. Paloviita and Ikonen also touch upon the issue of uncertainty, showing that government budgetary and macroeconomic forecasting errors have grown in Europe since the global financial crisis. Shifting to crisis responses, the paper by Soukiazis et al. applies a twin-deficit approach to model economic growth in Slovakia (one of the faster-growing transition countries in Central and Eastern Europe), highlighting the potential growth limitations associated with internal and external imbalances; their results suggest that crises can be avoided via appropriate competitiveness policies and price stability. Coming back to the role of the financial sector, Roman Horvath focuses on the fragmentation of financial markets in the EU, and how such fragmentation has reduced the effectiveness of monetary policy responses throughout the Eurozone. Finally, in regard to predicting the next crisis, Siranova and Radvansky evaluate the performance of individual early-warning indicators included in the EU's Macroeconomic Imbalance Procedure (MIP) framework, concluding that a parsimonious set of indicators is most effective in predicting imbalances for the future. In the concluding, and perhaps most provocative piece, Alberto Bagnai argues that a monetary union such as the Eurozone may actually be the source of macroeconomic divergence, creating capital misallocation and harming countries on the periphery.

Taken together, these papers address a topic of significance whose results will only be seen in time. However, the policy implications of these various pieces of research should be heeded in helping to design the next round of institutional responses, as well as the need for better-formulated policy mechanisms. The overall conclusion of these papers is that integration may not be finished, but it cannot continue in the manner in which it has been proceeding.

\section{REFERENCES}

Athanassiou, P. 2009. "Withdrawal and Expulsion from the EU and EMU: Some Reflections." European Central Bank, Legal Working Paper Series, 10.

Burns, C.J., Clifton, J., and Quaglia, L., 2017, "Explaining policy change in the EU: financial reform after the crisis." Journal of European Public Policy, Online First, pp. 1-19, http://dx.doi.org/10.1080/13501763.2017.1301535.

Cole, H.L. and Kehoe, T.J.. 2000. "Self-fulfilling debt crises." The Review of Economic Studies, 67(1), pp.91-116.

Saka, O., Fuertes, A.M. and Kalotychou, E., 2015. “ECB policy and Eurozone fragility: Was De Grauwe right?" Journal of International Money and Finance, 54, pp.168-185.

Zettelmeyer, J., Trebesch, C. and M. Gulati. 2013. "The Greek debt restructuring: an autopsy." Economic Policy, 28(75): 513-563.

Wyplosz, C. 2014. "The Eurozone Crisis: A Near-Perfect Case of Mismanagement." Economia Marche Journal of Applied Economics 33(1): 2-13. 
